\title{
Study of Chromium-Lead-Phosphate Glasses by XRD, IR, Density and Chemical Durability
}

\author{
Radouan Makhlouk1', Nadia Beloued1, Said Aqdim1,2* \\ ${ }^{1}$ Laboratory of Materials Engineering for Environment and Valorization, Faculty of Sciences, Hassan II University Ain Chock, \\ Casablanca, Morocco \\ ${ }^{2}$ Mineral Chemistry Laboratory, Department of Chemistry, Faculty of Science, Hassan II University Ain Chock, Casablanca, \\ Morocco \\ Email: *said_aq@yahoo.fr
}

How to cite this paper: Makhlouk, R., Beloued, N. and Aqdim, S. (2018) Study of Chromium-Lead-Phosphate Glasses by XRD, IR, Density and Chemical Durability. Advances in Materials Physics and Chemistry, 8, 269-280.

https://doi.org/10.4236/ampc.2018.86018

Received: April 13, 2018

Accepted: June 26, 2018

Published: June 29, 2018

Copyright $\odot 2018$ by authors and Scientific Research Publishing Inc. This work is licensed under the Creative Commons Attribution International License (CC BY 4.0). http://creativecommons.org/licenses/by/4.0/

\section{Open Access}

\begin{abstract}
Glasses in the ternary system $\mathrm{Cr}_{2} \mathrm{O}_{3}-\mathrm{PbO}-\mathrm{P}_{2} \mathrm{O}_{5}$ were prepared by direct melting of the mixture with stoichiometric proportions of the reagents $\mathrm{Cr}_{2} \mathrm{O}_{3}, \mathrm{PbO}$ and $\left(\mathrm{NH}_{4}\right)_{2} \mathrm{HPO}_{4}$ at $1080^{\circ} \mathrm{C}$. The glasses obtained are transparent in colour and have a non-hygroscopic appearance. The study of the dissolution rate was carried out on ternary glasses $\mathrm{xCr}_{2} \mathrm{O}_{3}-(45-\mathrm{x}) \mathrm{PbO}-55 \mathrm{P}_{2} \mathrm{O}_{5}$ with $(1 \leq \mathrm{x} \leq 4$; mol\%), immersed in distilled water at $90^{\circ} \mathrm{C}$ for 24 days, indicating a maximum of chemical durability when the level of chromium oxide passed through 2 mol\%. Both, IR spectra and X-ray diffraction have indicated the predominance of metaphosphate or cyclic metaphosphate groups with some traces of isolated orthophosphate groups when the $\mathrm{Cr}_{2} \mathrm{O}_{3}$ content is equal to $\mathrm{x}$ $=2$. Analysis of the density values also, has showed a maximum density for $\mathrm{x}$ $=2 \mathrm{~mol} \%$. The covalent radius values of oxygen have indicated that the minimum value $\mathrm{rcal}\left(\mathrm{O}^{2-}\right)$ is observed for $\mathrm{x}=2 \mathrm{~mol} \%$ and therefore a relatively high reinforcement of the metal-oxygen-phosphorus (Cr-O-P) bonds. SEM Micrographs have exhibited two phases, a vitreous phase and a crystalline phase. The radical change in the structure from ultraphosphate $\mathrm{Q}^{3}$ groups to ring metaphosphate $\mathrm{Q}^{2}$ and orthophosphate groups $\mathrm{Q}^{0}$ seems to be the cause of the formation of crystallites. Beyond $2 \mathrm{~mol} \%$ of $\mathrm{Cr}_{2} \mathrm{O}_{3}$, the structure of the glass changed relatively and the orthophosphate phases increased to the detriment of the metaphosphate phases. We observed a decrease in chemical durability. However, it was confirmed that the dissolution rate $\left(D_{R}\right)$ of the $S_{2}$ analysed compound is comparable to the values of borosilicate glasses which are used as alternative materials for the immobilisation of nuclear waste substances.
\end{abstract}

\section{Keywords}

Chemical Durability, Phosphate Glasses, Chromium Oxide, IR, XRD, SEM, 
Nuclear and Chemical Wastes

\section{Introduction}

The phosphate-based oxide glasses $\mathrm{P}_{2} \mathrm{O}_{5}$, compared to their silicate homologous, have important properties due to their low preparation temperatures. These properties, such as a low melting point, high coefficient of thermal expansion and optical properties, make these glasses potential candidates for many technological applications such as: medical field (biomaterials), solid electrolytes, vitrification of nuclear waste, etc. [1]-[10]. The lead iron phosphate glasses used for the disposal of nuclear waste were produced in 1984 [9]. The combination of chromium-doped phosphate glasses with different types of nuclear waste has shown that it is possible to have a waste form with a corrosion rate comparable to that of borosilicate glasses [2] [5] [7]. The previous work performed by our group demonstrated that the substitution of $\mathrm{Na}_{2} \mathrm{O}$ with lead oxide by more than $28 \mathrm{~mol} \%$, with the presence of $2 \mathrm{~mol} \%$ of $\mathrm{Cr}_{2} \mathrm{O}_{3}$ in the vitreous lattice appears to be an unfavourable factor for chemical durability. The phenomenon has been explained by the approach of the boundary zone between the crystal and the glass by the continuous formation of groups of isolated phosphate $\mathrm{PO}_{4}^{3-}$ [5] [6] [7] [11]. Hence, the crystallites exceed a certain limit, and the equilibrium between the glass bath and these crystallites are not longer maintained; we notice, once, a few decrease in the chemical durability. The purpose of this work is to study the evolution of the dissolution rate as a function of the chromium oxide content in distilled water at $90^{\circ} \mathrm{C}$ for the studied glasses of the series $\mathrm{xCr}_{2} \mathrm{O}_{3}-(45-\mathrm{x}) \mathrm{PbO}-55 \mathrm{P}_{2} \mathrm{O}_{5}$ with $(1 \leq \mathrm{x} \leq 4$; mol\%). The study of the dissolution rate, carried out on these glasses, reveals an important chemical durability for the low contents of chromium oxides ( $2 \mathrm{~mol} \%$ ).

\section{Experimental Section}

The synthesis of chromium lead phosphate glasses of composition $\mathrm{xCr}_{2} \mathrm{O}_{3}-(45-\mathrm{x}) \mathrm{PbO}-55 \mathrm{P}_{2} \mathrm{O}_{5}$ avec $(1 \leq \mathrm{x} \leq 4$; mol\%) was carried out by the direct fusion of mixtures of $\left(\mathrm{NH}_{4}\right)_{2} \mathrm{HPO}_{4}, \mathrm{~Pb}\left(\mathrm{NO}_{3}\right)_{2}$ and $\mathrm{Cr}_{2} \mathrm{O}_{3}$ in proper proportions. The reagents are finely crushed and then introduced into a porcelain crucible. They are heated to $300^{\circ} \mathrm{C}$ for $1 \mathrm{~h}$ in the first instance and then to $500^{\circ} \mathrm{C}$ for $1 \mathrm{~h}$ to complete their decomposition. The reaction mixture is then carried to $1050^{\circ} \mathrm{C} \pm$ $10^{\circ} \mathrm{C}$ for $15 \mathrm{~min}$. The liquid obtained is homogeneous. It is then poured on to an aluminium plate previously heated to $200^{\circ} \mathrm{C}$ to avoid thermal shocks. The vitreous state was first evidenced from the shiny and transparency aspect, which was then confirmed from the X-ray diffraction (XRD) patterns. Samples $S_{1}, S_{2}$ and $\mathrm{S}_{4}$ were respectively annealed at $560^{\circ} \mathrm{C}$ and $580^{\circ} \mathrm{C}$, for 72 hours. The chemical durability of these glasses was evaluated by the weight loss of the sample. The samples were polished by glass paper of silica carbon (CSI), cleaned with acetone 
and immersed in beakers of Pyrex containing $100 \mathrm{ml}$ of distilled water and brought to $90^{\circ} \mathrm{C}$. The surface of the sample must be constantly immersed in the distilled water for 24 days. The density of the glass has been measured at ambient temperature using the Archimedes method. The glass is immersed in a solution of diethyl orthophtalate density, depending on the temperature, is known. The precision is $0.05 \mathrm{~g} / \mathrm{cm}^{3}$. The density of the glass is given by the following equation:

$$
\rho=\frac{m_{\text {glass }}}{\left[m_{\text {glass }}+\left(m_{\text {ortho }}-m_{\text {ortho }+ \text { glass }}\right)\right]} \rho_{\text {ortho }}
$$

with:

$$
\begin{aligned}
& \rho=\text { Density } \\
& m_{\text {air }}=\text { Weight of glass measured in air } \\
& m_{\text {ortho }}=\text { Weight of diethyl orthophthalate only } \\
& m_{\text {ortho+glass }}=\text { Weight of glass immersed in diethyl orthophthalate } \\
& \rho_{\text {ortho }}=1.11422 \mathrm{~g} / \mathrm{cm}^{3}
\end{aligned}
$$

The infrared spectra of the phosphate glasses studied have been determined in the region between 1600 and $400 \mathrm{~cm}^{-1}$ with a resolution of $2 \mathrm{~cm}^{-1}$. The samples were finely ground and mixed with $\mathrm{KBr}$ (potassium bromide), which is transparent in the infrared, and whose role was to serve as a matrix.

Chemical composition of the departure mixture and some characteristics of the quaternary glasses, are summarized in Table 1.

\section{Results and Discussion}

\subsection{Analysis of Chemical Durability of Series $\mathrm{xCr}_{2} \mathrm{O}_{3}-(45-\mathrm{x}) \mathrm{PbO}-55 \mathrm{P}_{2} \mathrm{O}_{5}$}

The chemical durability $\left(\mathrm{D}_{\mathrm{R}}\right)$ of the glass is strongly dependent on its composition, in the case of the glass of the $\mathrm{xCr}_{2} \mathrm{O}_{3}-(45-\mathrm{x}) \mathrm{PbO}-55 \mathrm{P}_{2} \mathrm{O}_{5}$ composition series, the approximate durability analysis is carried out by measuring the dissolution rate $\left(D_{R}\right)$, which is defined as the weight loss of the glasses in $\mathrm{g} \cdot \mathrm{cm}^{-2} \cdot \mathrm{min}^{-1}$. The $D_{R}$ values shown in Table 1 show a very low dissolution rate for low levels of chromium oxide ( $2 \mathrm{~mol} \%$ of $\mathrm{Cr}_{2} \mathrm{O}_{3}$ ) introduced into the phosphate network to the detriment of $\mathrm{PbO}$. The substitution of $\mathrm{PbO}$ by $\mathrm{Cr}_{2} \mathrm{O}_{3}$ for more than $2 \mathrm{~mol} \%$ becomes an unfavourable factor for $\mathrm{D}_{\mathrm{R}}$. Figure 1 shows the variation in the

Table 1. Compositions, density and chemical durability of $\mathrm{xCr}_{2} \mathrm{O}_{3}-(45-\mathrm{x}) \mathrm{PbO}-55 \mathrm{P}_{2} \mathrm{O}_{5}$ with $(1 \leq \mathrm{x} \leq 4 ; \mathrm{mol} \%)$.

\begin{tabular}{ccccccc}
\hline $\begin{array}{c}\text { Glass } \\
\text { sample }\end{array}$ & $\begin{array}{c}\text { Starting glass composition } \\
(\mathrm{mol} \%)\end{array}$ & $\begin{array}{c}\mathrm{O} / \mathrm{P} \\
\text { ratio }\end{array}$ & $\begin{array}{c}\left(\mathrm{D}_{\mathrm{R}}\right) \\
\left(\mathrm{g} \cdot \mathrm{cm}^{-2} \cdot \mathrm{min}^{-1}\right)\end{array}$ & $\begin{array}{c}\rho \\
\left(\mathrm{g} / \mathrm{cm}^{3}\right)\end{array}$ \\
\hline & $\mathrm{Cr}_{2} \mathrm{O}_{3}$ & $\mathrm{PbO}$ & $\mathrm{P}_{2} \mathrm{O}_{5}$ & & 24 days & \pm 0.02 \\
$\mathrm{~S}_{1}$ & 1 & 44 & 55 & 2.92 & $(1.07 \pm 0.20) \times 10^{-6}$ & 4.175 \\
$\mathrm{~S}_{2}$ & 2 & 43 & 55 & 2.94 & $(5.79 \pm 0.20) \times 10^{-8}$ & 4.238 \\
$\mathrm{~S}_{3}$ & 3 & 42 & 55 & 2.96 & $(2.90 \pm 0.20) \times 10^{-7}$ & 4.134 \\
$\mathrm{~S}_{4}$ & 4 & 41 & 55 & 2.98 & $(2.02 \pm 0.20) \times 10^{-7}$ & 4.136 \\
\hline
\end{tabular}




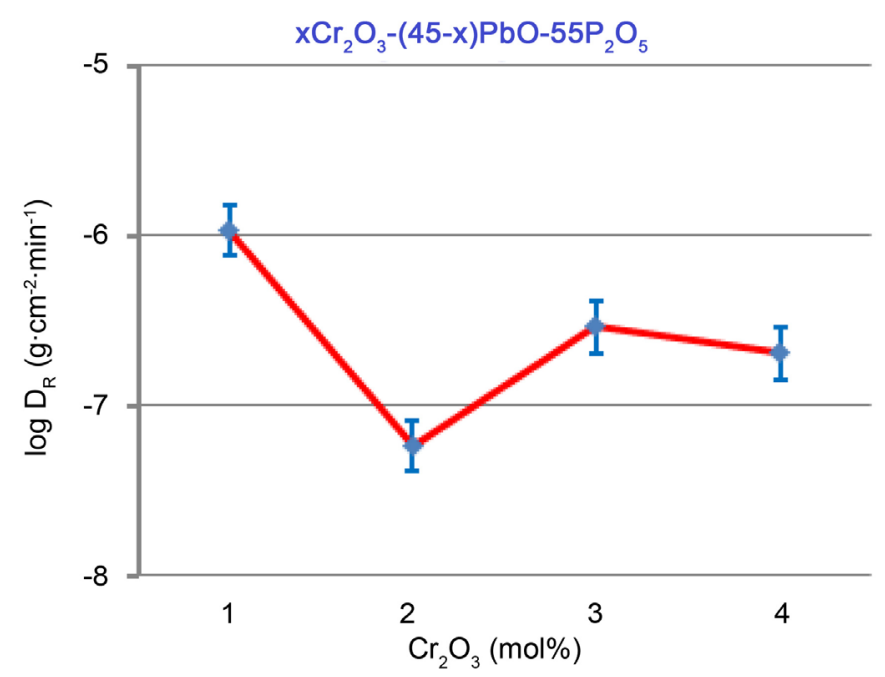

Figure 1. Chemical durability versus $\mathrm{Cr}_{2} \mathrm{O}_{3}$ for the series of composition $\mathrm{xCr}_{2} \mathrm{O}_{3}-(45-\mathrm{x}) \mathrm{PbO}-55 \mathrm{P}_{2} \mathrm{O}_{5}$.

dissolution rate of the glasses immersed in distilled water at $900^{\circ} \mathrm{C}$ for 24 days [6] [8] [11]. A progressive improvement of $D_{R}$ from $1.07 \times 10^{-6}$ to $5.80 \times 10^{-8}$ $\left(\mathrm{g} \cdot \mathrm{cm}^{2} \cdot \mathrm{min}\right.$ ) was noted when the $\mathrm{Cr}_{2} \mathrm{O}_{3}$ content varied from 1 to $2 \mathrm{~mol} \%$, respectively. However, we noted an increase in the dissolution rate $\left(D_{R}\right)$ from $5.80 \times$ $10^{-8}$ to $2 \times 10^{-7}\left(\mathrm{~g} \cdot \mathrm{cm}^{-2} \cdot \mathrm{min}^{-1}\right)$ when the $\mathrm{Cr}_{2} \mathrm{O}_{3}$ content varies from 2 to $4 \mathrm{~mol} \%$, respectively.

\subsection{Density and Molar Volumes}

Density measurements allowed us to follow the evolution of the molar volume depending on the composition of the system $\mathrm{xCr}_{2} \mathrm{O}_{3}-(45-\mathrm{x}) \mathrm{PbO}-55 \mathrm{P}_{2} \mathrm{O}_{5}$. The density measurements were completed at room temperature. As can be observed from the Figure 2, the variation in density versus $\mathrm{Cr}_{2} \mathrm{O}_{3}$ content (mol\%) indicates a maximum value of $\mathrm{x}=2$. The molar volume of oxygen $\left(V_{O M}\right)$ and the radius of anions of oxygen $r_{\text {cal }}\left(\mathrm{O}^{2-}\right)$ in the glass have been determined from Equations (1) and (2), respectively

$$
\begin{aligned}
& V_{O M}=M / \rho N_{A} N_{0}^{*} \\
& r_{\text {cal }}\left(\mathrm{O}^{2-}\right)=\frac{\sqrt[3]{V_{O M}}}{2}
\end{aligned}
$$

With $M=$ molar mass, $\rho=$ density, $N_{A}=$ Avogadro number; $N_{0}^{*}=$ number of oxygen atoms in the molecular formula. The value of the molar volume and the oxygen radius were calculated from the approximate hypothesis of close packing of oxygen anions $\mathrm{O}^{2-}$, having $r\left(\mathrm{O}^{2-}\right)$ recapitulated for each composition in Table 2 [12] [13] [14] [15]. A detailed analysis of the data in Table 2 shows that the molar volume passes through a minimum when the $\mathrm{Cr}_{2} \mathrm{O}_{3}$ content reaches $2 \mathrm{~mol} \%$. However, the covalent radius value of the oxygen atom $\left(\mathrm{O}^{2-}\right)$, calculated by the molar volume using the Equation (2) for each composition, seems to decrease slightly. 


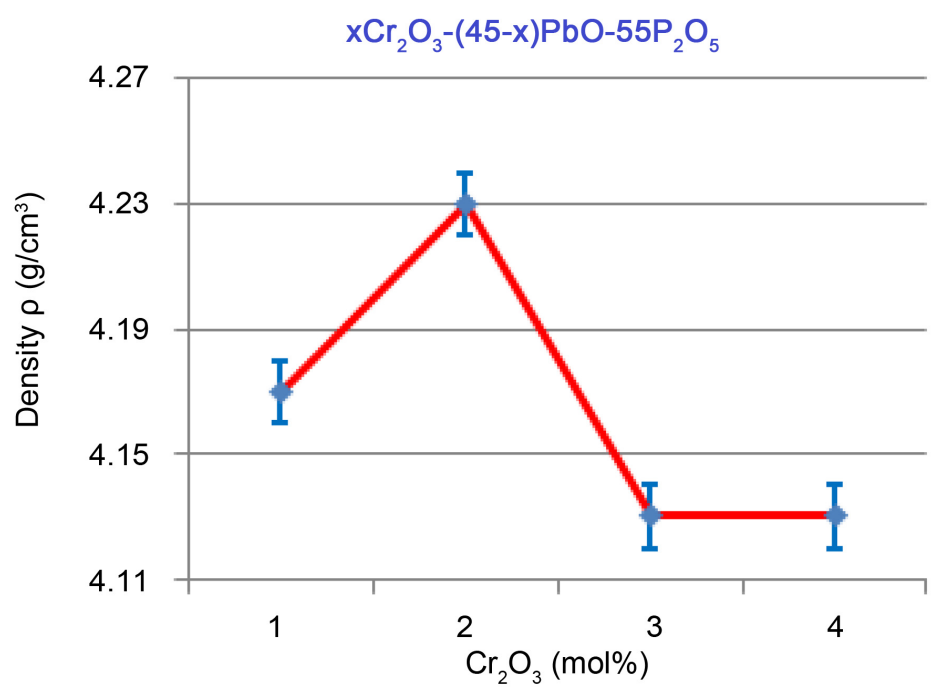

Figure 2. Variation of density versus $\mathrm{Cr}_{2} \mathrm{O}_{3}$ for the series of composition $\mathrm{xCr}_{2} \mathrm{O}_{3}-(45-\mathrm{x}) \mathrm{PbO}-55 \mathrm{P}_{2} \mathrm{O}_{5} \mathrm{Cr}_{2} \mathrm{O}_{3}(\mathrm{~mol} \%)$.

Table 2. Density and molar volume of system $\mathrm{xCr}_{2} \mathrm{O}_{3}-(45-\mathrm{x}) \mathrm{PbO}-55 \mathrm{P}_{2} \mathrm{O}_{5}$.

\begin{tabular}{|c|c|c|c|c|c|}
\hline Samples & $\begin{array}{c}\text { Molar formula } \\
\text { Oxygen/Mol }\left(\mathrm{N}_{\mathrm{O}}\right)\end{array}$ & $\begin{array}{l}\text { Molar } \\
\text { mass } \\
(\mathrm{g} / \mathrm{mol})\end{array}$ & $\begin{array}{c}\rho \\
\left(\mathrm{g} / \mathrm{cm}^{3}\right)\end{array}$ & $\begin{array}{c}\begin{array}{c}\text { Molar volume } \\
(\mathrm{nm})^{3}\end{array} \\
V_{O M}=M / \rho N_{A} N_{0}^{*}\end{array}$ & $\begin{array}{l}\text { Calculated } \\
\text { oxygen } \\
\text { radius } \\
(\mathrm{nm}) \\
r_{\text {cal }}\left(\mathrm{O}^{2-}\right)\end{array}$ \\
\hline S1 & $\begin{array}{c}1 \mathrm{Cr}_{2} \mathrm{O}_{3} \cdot 44 \mathrm{PbO} \cdot 55 \mathrm{P}_{2} \mathrm{O}_{5} \\
(322)\end{array}$ & $17,782.8$ & 4.175 & 0.0219 & 0.140 \\
\hline S2 & $\begin{array}{c}2 \mathrm{Cr}_{2} \mathrm{O}_{3} \cdot 43 \mathrm{PbO} \cdot 55 \mathrm{P}_{2} \mathrm{O}_{5} \\
(324)\end{array}$ & $17,711.6$ & 4.238 & 0.0214 & 0.138 \\
\hline S3 & $\begin{array}{c}3 \mathrm{Cr}_{2} \mathrm{O}_{3} \cdot 42 \mathrm{PbO} \cdot 55 \mathrm{P}_{2} \mathrm{O}_{5} \\
(326)\end{array}$ & $17,640.4$ & 4.134 & 0.0217 & 0.139 \\
\hline S4 & $\begin{array}{c}4 \mathrm{Cr}_{2} \mathrm{O}_{3} \cdot 41 \mathrm{PbO} \cdot 55 \mathrm{P}_{2} \mathrm{O}_{5} \\
(328)\end{array}$ & $17,569.2$ & 4.136 & 0.0215 & 0.139 \\
\hline
\end{tabular}

\subsection{Structural Approach by Infrared Spectroscopy}

The infrared spectra for the $\mathrm{xCr}_{2} \mathrm{O}_{3}-(45-\mathrm{x}) \mathrm{PbO}-55 \mathrm{P}_{2} \mathrm{O}_{5}$ glasses series (with $1 \leq \mathrm{x} \leq$ 4) are shown in Figure 3. As can be seen from this figure, all the phosphate vibration bands of the treated sample are presented in the frequency range between 1600 and $399 \mathrm{~cm}^{-1}$ [16] [17]. The band of approximately $1244-1228 \mathrm{~cm}^{-1}$ is attributed to the asymmetric vibration modes vas $\left(\mathrm{PO}_{2}\right)$ or the two non-bridging oxygen atoms linked to a phosphorus atom in the phosphate tetrahedron $\mathrm{Q}^{2}$ [17]. The vibrations of the bands around $1070-1047 \mathrm{~cm}^{-1}$ are characteristic of the stretching vibrations vasy $\left(\mathrm{PO}_{3}\right)$ and the terminal groups $v \mathrm{~s}$ $\left(\mathrm{PO}_{2}\right)$ [15] [16] [18]. The band about $912-894 \mathrm{~cm}^{-1}$ is attributed to the vasy P-O-P stretching vibrations [16] [17] [18] [19] [20], while the band at 779 - 771 


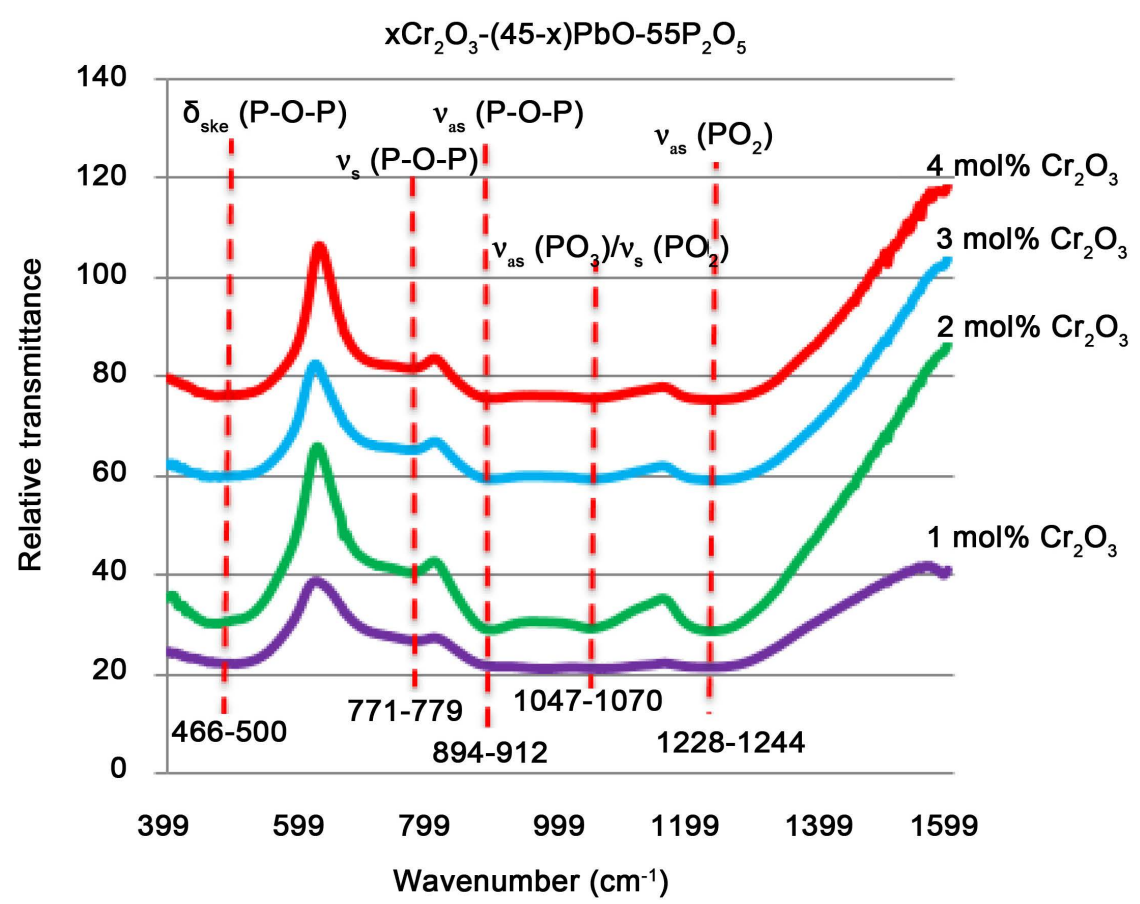

Figure 3. IR spectra of phosphate glasses of composition $\mathrm{xCr}_{2} \mathrm{O}_{3}-(45-\mathrm{x}) \mathrm{PbO}-55 \mathrm{P}_{2} \mathrm{O}_{5}$, with $(1 \leq \mathrm{x} \leq 4 ; \mathrm{mol} \%)$.

$\mathrm{cm}^{-1}$ is assigned to the stretching vibration $v_{\mathrm{sy}} \mathrm{P}-\mathrm{O}-\mathrm{P}$ band of the transition oxygen atoms of phosphorus to a phosphate tetrahedron $\mathrm{Q}^{1}$ [16] [19] [20] [21]. Bands that appear between 500 and $466 \mathrm{~cm}^{-1}$ are attributed to the P-O-P vibration modes of the skeleton [2] [16] [17] [19]. All characteristics of the phosphate vibrations show that the phosphate glasses of compositions $\mathrm{xCr}_{2} \mathrm{O}_{3}-(45-\mathrm{x}) \mathrm{PbO}-55 \mathrm{P}_{2} \mathrm{O}_{5}$ (with $\left.1 \leq \mathrm{x} \leq 4\right)$ may have chains or rings of the metaphosphate groups, with some traces of pyrophosphate groups. In fact, when the $\mathrm{Cr}_{2} \mathrm{O}_{3}$ content (mol\%) is equal to $\mathrm{x}=2$, the vibration bonds vas $\left(\mathrm{PO}_{2}\right)$ assigned to metaphosphates groups tend to be the dominant characteristic of the spectrum. As shown in Figure 3, the band becomes more intense.

\subsection{X-Ray Diffraction}

The XRD pattern shown in the Figure 4 indicates that the local structure of chromium-lead phosphate glasses, evolved from ultraphosptate $(\mathrm{O} / \mathrm{P}=2.93)$ to nearby chains (cyclic metaphosphate $\mathrm{O} / \mathrm{P}=3$, isolated orthophosphates $\mathrm{O} / \mathrm{P}=4$ ) structures $\mathrm{Cr}\left(\mathrm{PO}_{3}\right)_{3}, \mathrm{Cr}_{2}\left(\mathrm{PO}_{3}\right)_{6}, \mathrm{~Pb}\left(\mathrm{PO}_{3}\right)_{2}, \mathrm{~Pb}_{2}\left(\mathrm{PO}_{3}\right)_{4}, \mathrm{~Pb}_{3}\left(\mathrm{PO}_{4}\right)_{2}, \mathrm{~Pb}_{9}\left(\mathrm{PO}_{4}\right)_{6}$, $\mathrm{Pb}_{3} \mathrm{Cr}\left(\mathrm{PO}_{4}\right)_{3}$ and some trace of $\mathrm{Pb}_{2} \mathrm{P}_{2} \mathrm{O}_{7}$. When the sample $\mathrm{S}_{1}$ was thermally treated at $560^{\circ} \mathrm{C}$, the amorphous phase partially disappeared and major $\mathrm{Cr}$ $\left(\mathrm{PO}_{3}\right)_{3}$ [JCDDS FileN ${ }^{\circ}$ : 01-077-0672], $\mathrm{Pb}\left(\mathrm{PO}_{3}\right)_{2}$ [JCDDS. File $\mathrm{N}^{\circ}$ : 00-043-0335], $\mathrm{Pb}_{2}\left(\mathrm{PO}_{3}\right)_{4}$ [JCDDS File $\mathrm{N}^{\circ}:$ 01-086-21] Phases occurred in the sample, with minor $\mathrm{Pb}_{3}\left(\mathrm{PO}_{4}\right)_{2}$ [JCDDS File $\mathrm{N}^{\circ} 01-070-1790$ ] and $\mathrm{Pb}_{9}\left(\mathrm{PO}_{4}\right)_{6}$ [JCDDS file $\mathrm{N}^{\circ}$ : 00033-0768] Phases. When the $\mathrm{Cr}_{2} \mathrm{O}_{3}$ content increased in the glass $\left(\mathrm{S}_{2}\right)$, the heat treatment caused an increase in crystallization temperature at $580^{\circ} \mathrm{C}$, which 

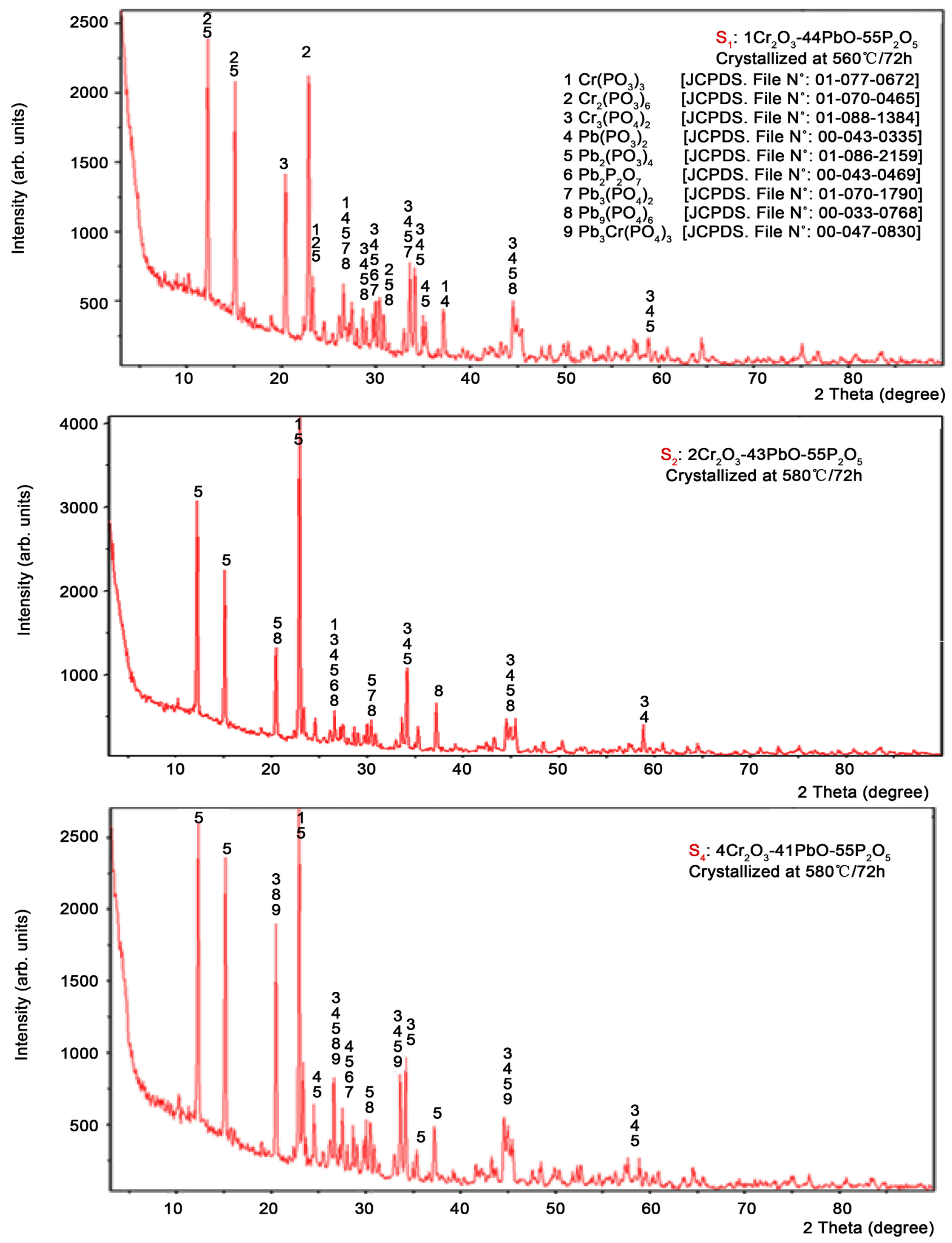

Figure 4. X-ray spectrum of the glasses of compositions $\mathrm{S}_{1}, \mathrm{~S}_{2}$ and $\mathrm{S}_{4}$ devitrified respectively at $560^{\circ} \mathrm{C}, 580^{\circ} \mathrm{C}$ and $56^{\circ} \mathrm{C}$ for 72 hours. 
resulted in the disappearance of isolated orthophosphate phase and the formation of $\left.\mathrm{CrPO}_{3}\right)_{3}, \mathrm{~Pb}_{2}\left(\mathrm{PO}_{3}\right)_{4}$ and $\mathrm{Pb}\left(\mathrm{PO}_{3}\right)_{2}$. However, the $\mathrm{S}_{4}$ sample thermally treated at $560^{\circ} \mathrm{C}$, indicate the formation of metaphosphate and/or rings of metaphosphate phase $\mathrm{Cr}\left(\mathrm{PO}_{3}\right)_{3}, \mathrm{~Pb}_{2}\left(\mathrm{PO}_{3}\right)_{4}$ with the appearance of isolated orthophosphate phase $\mathrm{Pb}_{9}\left(\mathrm{PO}_{4}\right)_{6}$ and $\mathrm{Pb}_{3} \mathrm{Cr}\left(\mathrm{PO}_{4}\right)_{3}$ [JCDDS File $\mathrm{N}^{\circ}$ : 00-047-0830] at the expense of metaphosphate phases [6] [22] [23].

\subsection{SEM Micrograph}

SEM images in Figure 5 illustrate the morphology of the glasses considered in

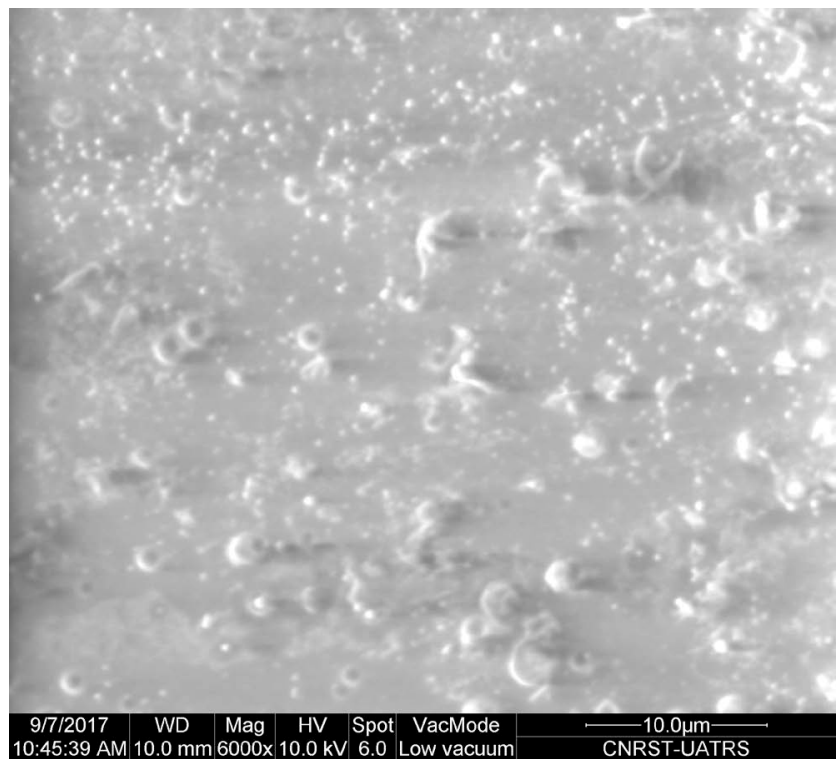

(a)

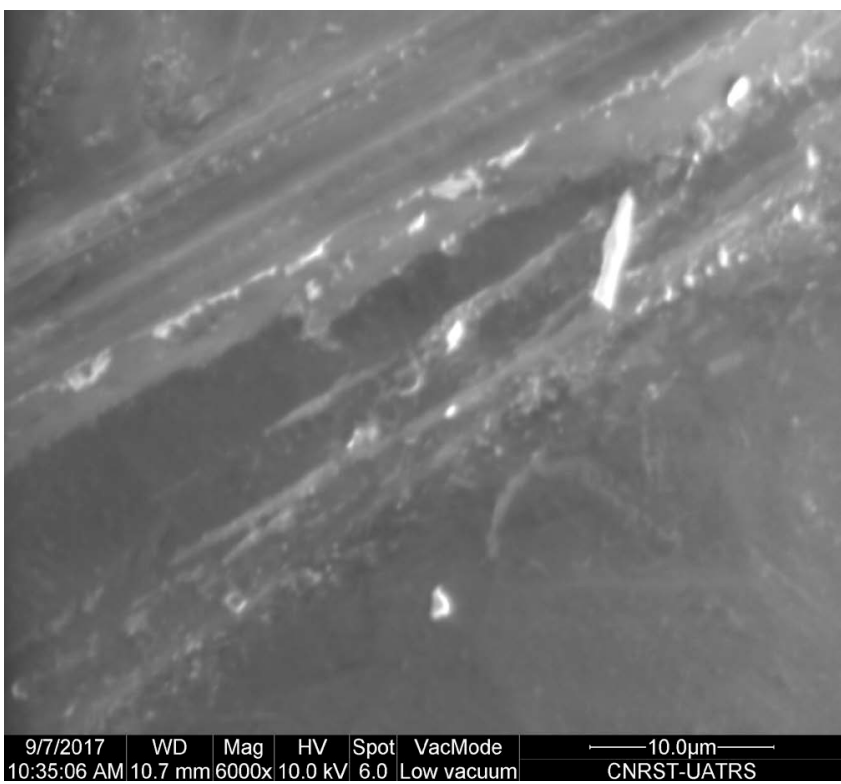

(b)

Figure 5. SEM micrograph showing the visual structure of the samples glasses $\mathrm{S}_{2}(\mathrm{a})$ and $\mathrm{S}_{4}(\mathrm{~b})$. 
this work. The glass form of $S_{2}$, shown in Figure 5(a), exhibits two phases, a vitreous phase and a crystalline phase. This last one indicates the formation of crystalline agglomerates particle having ring form that indicate, the crystallisation tendency is enhanced and major $\mathrm{Cr}\left(\mathrm{PO}_{3}\right)_{3}$ and $\mathrm{Pb}_{2}\left(\mathrm{PO}_{3}\right)_{4}$ phases are crystallised in these glasses. The presence of the crystalline phase seems to explain the increase in chemical durability [14] [15] [16]. The SEM micrograph for the sample $\mathrm{S}_{4}$ indicates a radical change in the structure. There is formation of crystalline phase agglomerates of various sizes, ranging from some microns. This probably explains the structural change towards more short isolated orthophosphate chains as the $\mathrm{Cr}_{2} \mathrm{O}_{3}$ content increases in the glass network.

\section{Discussion}

The structure and the chemical durability of the glasses series $\mathrm{xCr}_{2} \mathrm{O}_{3}-(45-\mathrm{x}) \mathrm{PbO}-55 \mathrm{P}_{2} \mathrm{O}_{5}$ (with $1 \leq \mathrm{x} \leq 4$; mol\%) have been investigated using various techniques such as density, $\mathrm{X}$-Ray diffraction and IR. The measured properties indicate that the glasses series chromium-lead-phosphorus-oxygen network become stronger for $\mathrm{x}=2$. $\mathrm{X}$-ray diffraction indicates that the samples $\mathrm{S}_{1}, \mathrm{~S}_{2}$ and $\mathrm{S}_{4}$, respectively annealed at $560^{\circ} \mathrm{C}$ and $580^{\circ} \mathrm{C}$ for $72 \mathrm{~h}$, contain metaphosphates, orthophosphates and certain traces of pyrophosphate phases in all the glasses. When the $\mathrm{Cr}_{2} \mathrm{O}_{3}$ content is equal to $2 \mathrm{~mol} \%, \mathrm{X}$ ray diffraction and IR spectra, both, confirmed the predominance of metaphosphate groups most probably cyclic. The bands at $1244-1228 \mathrm{~cm}^{-1}$, attributed to the asymmetric vibration modes vas $\left(\mathrm{PO}_{2}\right)$, become more intense. The predominance of cyclic metaphosphate chains as $\mathrm{Cr}\left(\mathrm{PO}_{3}\right)_{3}$ and $\mathrm{Pb}_{2}\left(\mathrm{PO}_{3}\right)_{4}$ have led to maximum chemical durability. Analysis of the density values also showed a maximum density for $\mathrm{x}=2 \mathrm{~mol} \%$. The covalent radius values of oxygen calculated from Equation (2) indicate that the minimum value $\mathrm{rcal}\left(\mathrm{O}^{2-}\right)$ is observed for $\mathrm{x}=2 \mathrm{~mol} \%$ and therefore a relatively high reinforcement of the metal-oxygen-phosphorus (Cr-O-P) bond. Additionally, because of the big stability of the energy of field of ligand of $\mathrm{d}^{3}$ systems in octahedral symmetry, the ions $\mathrm{Cr}^{3+}$ occupy almost exclusively the sites having this symmetry type [23] [24], while the $\mathrm{Pb}$ is estimated to be in the tetrahedral site forming $\mathrm{PbO}_{4}$ pyramids which are connected in phosphate tetrahedron by covalent links $\mathrm{P}-\mathrm{O}-\mathrm{Pb}$ [25] [26]. Above $2 \mathrm{~mol} \% \mathrm{Cr}_{2} \mathrm{O}_{3}$, the glass structure changes relatively, it is found that the DRX spectra intensity of the ring metaphosphate phases decreases, whereas the appearance of the isolated orthophosphate phase becomes important when the $\mathrm{Cr}_{2} \mathrm{O}_{3}$ content reaches 4 mol\%. The substitution of $\mathrm{PbO}$ with chromium oxide by more than $2 \mathrm{~mol} \%$ in the vitreous lattice appears to be an unfavorable factor for chemical durability. The origin of this phenomenon is explained almost probably by the approach of the boundary zone between the crystal and the glass by the continuous formation of groups of isolated phosphate $\mathrm{PO}_{4}^{3-}$ [6] [19]. The decrease of chemical durability observed, can be also explained by the existence of the critical concentrations between the cation ions beyond which each ion seeks, by competition, to 
have a site that is appropriate to it by moving away from the other. This behavior leads to an increase in the glass volume and a relaxation of the structure [27] [28] and consequently a decrease in density and chemical durability. On the other hand, the $\mathrm{PbO}$ oxide have à low melting temperature and can participated with $\mathrm{P}_{2} \mathrm{O}_{5}$ Oxyde, basis glass matrix, in the extend of the area glass. That explains probably the non evidence of the attributed band of orthophosphate isolated units in the IR spectra beside the X-ray diffraction spectra. Added, the elaboration method of the glasses (melting temperature, tempering speed, etc.) remains a significant factor in the deep understanding of the phenomenon [29].

\section{Conclusion}

The structure and the chemical durability of chromium lead phosphate glasses of composition $\mathrm{xCr}_{2} \mathrm{O}_{3}-(45-\mathrm{x}) \mathrm{PbO}-55 \mathrm{P}_{2} \mathrm{O}_{5}$ avec $(1 \leq \mathrm{x} \leq 4$; mol\%) have been investigated using various techniques such IR, X-ray diffraction, density and SEM micrograph. The study of the dissolution rate carried out on the glasses, immersed in distilled water at $90^{\circ} \mathrm{C}$ for 24 days, indicates a maximum chemical durability when the level of chromium oxide passes through $2 \mathrm{~mol} \%$. The analysis of the values of the density also showed a maximum density for $\mathrm{x}=2 \mathrm{~mol} \%$. The covalent radius values of the oxygen indicate that the minimum values are observed for $\mathrm{x}=2 \mathrm{~mol} \%$, and therefore, a relatively high reinforcement of the metal-oxygen-phosphorus (Cr-O-P) bonds. However, the increase in the $\mathrm{Cr}_{2} \mathrm{O}_{3}$ content in the vitreous network to the detriment of $\mathrm{PbO}$ beyond $2 \mathrm{~mol} \%$, is an unfavourable factor for both chemical durability and density. The increase in the $\mathrm{Cr}+\mathrm{Pb} / \mathrm{P}$ ratio leads to an increase in the number of metal-O-P bonds which cause a high tendency for crystallisation and confirms that the dissolution rate $\left(D_{R}\right)$ of the analyzed compounds is comparable to the values of borosilicate glasses and 40 times less than BaBal glasses which are used as alternative materials for the immobilisation of nuclear waste substances.

\section{Acknowledgements}

The authors wish to thank National Center for Scientific and Technical Research [Division of Technical Support Unit for Scientific Research (TSUSR) Rabat, Morocco] for their assistance to the realization of this work.

\section{References}

[1] Velli, L.L., Varsamis, C.P.E., Kamitsos, E.I., Möncke, D. and Ehrt, D. (2005) Structural Investigation of Metaphosphate Glasses. Physics and Chemistry of Glasses-European Journal of Glass Science and Technology Part B, 46, 178-181.

[2] Aqdim, S. (2007) Investigation des phases vitreuses des systèmes $(\mathrm{Li}, \mathrm{Na})_{2} \mathrm{O}-(\mathrm{Fe}, \mathrm{Al})_{2} \mathrm{O}_{3}-\mathrm{P}_{2} \mathrm{O}_{5}$ par Spectroscopies Infrarouge et Mössbauer-Structures et Durabilité chimique. These, Faculté des Sciences de Casablanca Ain Chock, Morocco.

[3] Mbemba, K.M. (2010) Etude de la durabilité chimique des verres alcali-résistants de type cemfil synthétisés à partir des refiom en vue de les valoriser comme renforts 
dans les matrices cimentaires. These Universite Paris-Est, France.

[4] El Hadrami, A. (2003) Etude des conditions de confinements du plomb et du cadmium dans des verres à base de méta-phosphates de zinc. Université Cadi Ayyad Marrakech, Maroc.

[5] Videau, J.J. and Gilles, F. (2010) Les verres phosphates de la spécificité de l'atome de phosphore à la formation, la structure et la durabilité chimique de phosphates vitreux. Institut de Chimie de la Matière Condensée de Bordeaux, CNRS, Université de Bordeaux, France.

[6] Beloued, N., Chabbou, Z. and Aqdim, S. (2016) Correlation between Chemical Durability Behaviour and Structural Approach of the Vitreous Part of the System $55 \mathrm{P}_{2} \mathrm{O}_{5}-2 \mathrm{Cr}_{2} \mathrm{O}_{3}-(43-\mathrm{x}) \mathrm{Na}_{2} \mathrm{O}-\mathrm{xPbO}$. Advances in Materials Physics and Chemistry, 6, 149-156. https://doi.org/10.4236/ampc.2016.66016

[7] Santic, A., Skoko, Z., Gajovic, A., Reis, S.T., Day, D.E. and Mogus-Milankovic, A. (2011) Physical Properties of Lead Iron Phosphate Glasses Containing $\mathrm{Cr}_{2} \mathrm{O}_{3}$. Journal of Non-Crystalline Solids, 357, 3578-3584.

https://doi.org/10.1016/j.jnoncrysol.2011.07.011

[8] Makhkhas, Y., Aqdim, S. and Sayouty, E.H. (2013) Study of Sodium-ChromiumIron-Phosphate Glass by XRD, IR, Chemical Durability and SEM. Journal of Materials Science and Chemical Engineering, 1, 1-6.

https://doi.org/10.4236/msce.2013.13001

[9] Sales, B.C. and Boatner, L.A. (1984) Lead-Iron Phosphate Glass: A Stable Storage Medium for High-Level Nuclear Waste. Sciences, 226, 45-48.

https://doi.org/10.1126/science.226.4670.45

[10] El-Egili, K., Doweidar, H., Moustafa, Y.M. and Abbas, I. (2008) Structure and Some Properties of $\mathrm{PbO}-\mathrm{P}_{2} \mathrm{O}_{5}$ Glasses. Physica B, 339, 237-245. https://doi.org/10.1016/j.physb.2003.07.005

[11] Errouissi, Y., Chabbou, Z., Beloued, N. and Aqdim, S. (2017) Chemical Durability and Structural Properties of $\mathrm{Al}_{2} \mathrm{O}_{3}-\mathrm{CaO}-\mathrm{Na}_{2} \mathrm{O}-\mathrm{P}_{2} \mathrm{O}_{5}$ Glasses Studied by IR Spectroscopy, XRD and SEM. Advances in Materials Physics and Chemistry, 7, 353-363. https://doi.org/10.4236/ampc.2017.710028

[12] Ouchetto, M. (1993) Caractérisation et Approche structural de la région vitreuse du système ternaire $\mathrm{Li}_{2} \mathrm{O}-\mathrm{CdO}-\mathrm{P}_{2} \mathrm{O}_{5}$. Diplôme d'étude de $3^{\text {ème }}$ Cycle Sciences Physiques, Faculty of Sciences Rabat, University Mohammed V, Morocco.

[13] Aqdim, S., Elouadi, B. and Grenech, J.M. (2012) Chemical Durability and Structural Approach of the Glass Series (40-y) $\mathrm{Na}_{2} \mathrm{O}-\mathrm{yFe} \mathrm{O}_{2}-5 \mathrm{Al}_{2} \mathrm{O}_{3}-55 \mathrm{P}_{2} \mathrm{O}_{5}$-by IR, X-Ray Diffraction and Mössbauer Spectroscopy. Material Sciences and Engineering, 27, Article ID: 012003. https://doi.org/10.1088/1757-899X/28/1/012003

[14] Chabbou, Z. and Aqdim, S. (2014) Chemical Durability and Structural Proprieties of the Vitreous Part of the System xCaO- $(40-\mathrm{x}) \mathrm{ZnO}-15 \mathrm{Na}_{2} \mathrm{O}-45 \mathrm{P}_{2} \mathrm{O}_{5}$. Advances in Materials Physics and Chemistry, 4, 179-180. http://dx.doi.org/10.4236/ampc.2014.410021

[15] Santic, A., Mogus-Milankovic, A., Furic, K., Bermanec, V., Kim, D.W. and Daye, D.E. (2007) Structural Properties of $\mathrm{Cr}_{2} \mathrm{O}_{3}-\mathrm{Fe}_{2} \mathrm{O}_{3}-\mathrm{P}_{2} \mathrm{O}_{5}$ Glasses, Part I. Journal of Non-Crystalline Solids, 353, 1070-1077. http://dx.doi.org/10.1016/j.jnoncrysol.2006.12.104

[16] Aqdim, S. and Albizane, A. (2015) Structural Feature and Chemical Durability of Sodium Aluminium Iron Phosphate Glasses. Journal of Environmental Science, Computer Science and Engineering \& Technology, 4, 509-521.

[17] Aqdim, S. and Ouchetto, M. (2013) Elaboration and Structural Investigation of Iron 
(III) Phosphate Glasses. Advances in Materials Physics and Chemistry, 3, 332-339. https://doi.org/10.4236/ampc.2013.38046

[18] Reis, S.T., Faria, D.L.A., Martinelli, J.R., Pontuschka, W.M., Day, D.E. and Partiti, C.S.M. (2002) Structural Features of Lead Iron Phosphate Glasses. Journal of Non-Crystalline Solids, 304, 188-194. https://doi.org/10.1016/S0022-3093(02)01021-9

[19] Aqdim, S., Errouissi, Y., Cherif, A. and Makhlouk, R. (2017) Elaboration and Characterization of Glasses and Ceramic-Glasses within Theternary Diagram $\mathrm{Li}_{2} \mathrm{O}-\mathrm{Cr}_{2} \mathrm{O}_{3}-\mathrm{P}_{2} \mathrm{O}_{5}$. Advances in Materials Physics and Chemistry, 7, 123-137. https://doi.org/10.4236/ampc.2017.74011

[20] Bernardo, E., Varrasso, M., Cadamuro, F. and Hreglich, S. (2006) Vitrification of Wastes and Preparation of Chemically Stable Sintered Glass-Ceramic Products. Journal of Non-Crystalline Solids, 352, 4017-4023. https://doi.org/10.1016/j.jnoncrysol.2006.07.001

[21] Drabarek, E., McLeod, T.I., Hanna, J.V., Griffith, C.S. and Luca, V. (2009) Tungstate-Based Glass-Ceramics for the Immobilization of Radio Cesium. Journal of Nuclear Materials, 384, 119-129. https://doi.org/10.1016/j.jnucmat.2008.11.018

[22] Joseph, K., Jolley, K. and Smith, R. (2015) Iron Phosphate Glasses: Structure Determination and Displacement Energy Thresholds, Using a Fixed Charge Potential Model. Journal of Non-Crystalline Solids, 411, 137-144. https://doi.org/10.1016/j.jnoncrysol.2014.12.033

[23] Santic, A., Kim, C.W., Day, D.E. and Mogus-Milankovic, A. (2010) Electrical Properties of $\mathrm{Cr}_{2} \mathrm{O}_{3}-\mathrm{Fe}_{2} \mathrm{O}_{3}-\mathrm{P}_{2} \mathrm{O}_{5}$ Glasses. Part II. Journal of Non-Crystalline Solids, 356, 2699-2703. https://doi.org/10.1016/j.jnoncrysol.2010.09.072

[24] Moss, R.M., Neel, E.A.A., Pickup, D.M., Twyman, H.L., Martin, R.A., Henson, M.D. and Newport, R.J. (2010) The Effect of Zinc and Titanium on the Structure of Calcium-Sodium Phosphate Based Glass. Journal of Non-Crystalline Solids, 356, 1319-1324. https://doi.org/10.1016/j.jnoncrysol.2010.03.006

[25] El Hadrami, A. (2003) Etude de condition de confinement du plomb et du cadmium dans des verres à base de metaphosphate de Zinc. Université Cadi Ayyad, Marrackech, Maroc, Université Bourdeaux 1.

[26] Liu, H.S., Chin, T.S. and Yung, S.W. (1997) FTIR and XPS Studies of Low-Melting $\mathrm{PbO}-\mathrm{ZnO}-\mathrm{P}_{2} \mathrm{O}_{2}$ Glasses. Materials Chemistry and Physics, 50, 1-10. https://doi.org/10.1016/S0254-0584(97)80175-7

[27] Treis, S., Pontuschka, W.M., Partiti, G.S.M. and Faria, D.L.A. (2001) Proprieties and Structural Features of Basal Glasses.

[28] Mogus-Milankovic, A., Santic, B., Day, D.E. and Ray, C.S. (2001) Electrical Conductivity in Mixed-Alkali Iron Phosphate Glasses. Journal of Non-Crystalline Solids, 283, 119-128. https://doi.org/10.1016/S0022-3093(01)00355-6

[29] Chanshetti, U.B., Shelke, V.A., Jadhav, S.M., Shankarwar, S.G., Chondhekar, T.K., Shankarwar, A.G. and Jogad, M.S. (2011) Density and Molar Volume Studies of Phosphate Glasses. Facta Universitatis-Series. Physics, Chemistry and Technology, 9, 29-36. https://doi.org/10.2298/FUPCT1101029C 